\title{
Permeability of a fault zone crosscutting a sequence of sandstones and shales and its influence on hydraulic head distribution in the Chatsworth Formation, California, USA
}

\author{
Antonino Cilona $\cdot$ Atilla Aydin • Nicholas M. Johnson
}

\begin{abstract}
Faults influence groundwater flow paths. The transport of groundwater contaminants within the faulted sandstones and shales of Chatsworth Formation exposed in southern California, USA, have been investigated. Structural and hydrogeological data are combined to interpret the hydraulic-head drop measured across a fault with tens of meters of oblique-slip. The fault zone architecture was delineated at two locations: an outcrop and a borehole intersecting the fault at depth. At the first station, the fault juxtaposes sandstones against shales with a fault core mostly consisting of deformed shale. A series of shale beds striking parallel to the fault zone and dipping $\sim 50^{\circ}$ toward the fault zone provides evidence that the shale was incorporated into the fault zone. At the second station, borehole images show a plane juxtaposing fractured sandstone against shale-rich fault rock. Hydraulic heads measured at 30 wells show a drop of $75 \mathrm{~m}$ across the fault, which is interpreted to be a result of the low-permeability shaley fault rock. It is proposed that the shale was incorporated into the fault zone by shale smearing. These results are consistent with numerical modeling, which requires a low-permeability fault core to simulate the observed hydraulic head differences. Understanding the hydraulic nature of this fault provides a critical constraint for evaluating the future migration of contaminants in the groundwater system.
\end{abstract}

Keywords Fault permeability - Shale smearing · Hydraulic head · Contamination · USA

\section{Introduction}

Fluid flow across and along fault zones has repercussions on numerous practical applications because faults are

Received: 7 June 2014 / Accepted: 22 October 2014

Published online: 20 November 2014

(C) The Author(s) 2014. This article is published with open access at Springerlink.com

\author{
A. Cilona ( $(-)$ A. Aydin \\ Department of Geological and Environmental Sciences, \\ Stanford University, Stanford, CA, USA \\ e-mail: cilona@stanford.edu \\ N. M. Johnson \\ MWH Americas Inc., Walnut Creek, CA, USA
}

common in aquifers and reservoirs and their hydraulic behaviors affect flow pathways (Caine et al. 1996; Aydin 2000; Bense et al. 2008; Rotevatn and Fossen 2011; Antonellini et al. 2014). In general, this effect depends on the hydraulic properties of the faults and the associated fracture systems relative to those of the surrounding host rocks. Where fault zones have a lower permeability relative to the host rock, they can impede cross-fault fluid flow (Antonellini and Aydin 1994). Conversely, in tight lithologies, fault zones may have higher permeability and may act as fluid conduits that focus fluid flow (Faulkner et al. 2010; Aydin 2014). Fault hydraulic behavior may evolve in time and space during fault development, such that faults showing a complex conduit-barrier behavior are also common (Bredehoeft et al. 1982; Taylor et al. 1999; Flodin et al. 2005; Mitchell and Faulkner 2009; Agosta et al. 2012).

The permeability of a fault zone is controlled by the fault architecture, its components, and the way in which these components are distributed. Whereas the fault architecture is mostly controlled by the type, geometry, distribution, connectivity, and density of structures constituting fault zones (Caine et al. 1996; Micarelli et al. 2006), the nature of fault rocks (e.g., breccia, cataclasite, gouge) is related to the host rock lithology and the processes responsible for the formation of the fault zones. Two of the most common processes that produce lowpermeability fault rocks are shale or clay smearing and cataclasis (Yielding et al. 1997; Aydin and Eyal 2002; Balsamo et al. 2010). Shale smearing is the mechanism for incorporating shale into fault zones, which involves the ductile behavior of the shale and the development of clayrich fault rocks (Aydin and Eyal 2002; Eichhubl et al. 2005). Cataclasis is a friction-dependent, brittle process that causes comminution through grain rotation, translation, and fracturing (Engelder 1974).

The permeability structure of fault zones has been investigated by hydrogeologists and structural geologists using two separate lines of research: one based on flow data (Cohen 1999; Celico et al. 2006; Petrella et al. 2014) and one generally focused on the structural architecture of natural fault zones (Caine et al. 1996; Aydin 2000). There have been limited attempts to combine insights or integrate the knowledge and experience gained from these 
two disciplines (see Bense et al. 2013 for a recent review of the subject).

In this multidisciplinary study, an attempt is made to use the structural architecture of a relatively large fault zone to interpret the distribution of hydraulic head data measured along and across the fault. The fault zone crosscuts a thick turbidite sequence of sandstones and shales belonging to the Chatsworth Formation (Fig. 1; Colburn et al. 1981; Link et al. 1981), which is extensively exposed across the Simi Hills in southern California, USA. The data presented here were collected from an inactive industrial research and development facility (Santa Susana Field Laboratory or SSFL) located in the Simi Hills (Fig. 1b-c). The space aeronautics and energy research activities (i.e., testing and development of rocket engines from 1949 to 2006, nuclear reactors from 1953 to 1980 , and liquid metals research from 1966 to 1998) carried out at this site during past decades resulted in chemical contamination (mostly trichloroethylene) of the groundwater system underlying the study area (CH2MHill 1993; Cherry et al. 2009).

With the aim of deciphering the contaminant migration pathways as well as designing an efficient remediation strategy, groundwater head levels and chemical concentrations have been monitored for more than two decades across a system consisting of hundreds of wells and piezometers. The Santa Susana Field Laboratory represents a unique opportunity for integrating hydrogeology and structural geology. The outcomes of this study provide new insights for explaining the distribution of groundwater head and contaminant plume migration as a result of the architecture and permeability structure of a large fault zone crosscutting a turbidite sequence. Moreover, the results from the study may be applied for modeling the hydrogeological behavior of similar fault zones and improving contaminant transport models used to describe and predict plume behavior in groundwater systems.

\section{Geological setting}

The Simi Hills are bounded to the north by Simi Valley and the Santa Susana Mountains, to the west by San Fernando Valley, and to the south by the Santa Monica Mountains, and occupy a portion of the easternmost Western Transverse Ranges (Fig. 1b). Since early-middle Miocene, the Western Transverse Ranges have undergone up to $90^{\circ}$ clockwise rotation around a vertical axis located near the present southeast corner of the region (Nicholson et al. 1994). This rotation was synchronous with or shortly followed (12-14 Ma) by an extensional phase. In the early Pliocene, the deformation within the area became strongly compressive, with an approximate north-south oriented shortening (Nicholson et al. 1994; Langenheim et al. 2011).

Local bedrock strata in and proximal to the study area typically range in age from Late Cretaceous to late Pliocene, and are marine, nonmarine, and volcanic in origin. The oldest stratigraphic unit exposed in the Simi Hills is the Upper Cretaceous Chatsworth Formation (Fig. 1). Within SSFL, exposures of the Chatsworth Formation strata consist primarily of sandstones interbedded with shales, siltstones, and conglomerates with typical bedding strike of approximately $\mathrm{N} 70^{\circ} \mathrm{E}$ and dips of 25 $35^{\circ} \mathrm{NW}$ (Fig. 1c). It is believed that this formation deposited in a turbidite mid-fan environment (Link et al. 1984).

In the study area and its vicinity, the Chatsworth Formation is subdivided informally into upper and lower units (Fig. 1d; Montgomery Watson 2000), with the upper unit further subdivided into stratigraphic packages and members based on the predominant grain size (Fig. 1d). Coarser-grained members consist primarily of medium- to fine-grained sandstone beds (Fig. 1d) characterized by features typical of turbidite deposits (Bouma 1962). Intervals of stacked sandstone beds with few or no finegrained interbeds typically reach a few meters thick and may extend laterally for several hundreds of meters (Fig. 1c). The finer-grained members of the upper part of the formation typically consist of $50 \%$ or more siltstone and shale, inter-bedded with lesser amounts of sandstone. Within the study area, the upper part of the Chatsworth Formation is subdivided into two stratigraphic packages dominated by coarse-grained facies referred to as Sandstone 1 and Sandstone 2 (MWH 2009). These two packages are separated and bounded above and below by predominantly fine-grained facies packages referred to as Shale 1, Shale 2, and Shale 3, from bottom to top (Fig. 1d). Sandstones 1 and 2 are each in turn subdivided into three coarse-grain dominant members separated by predominantly fine-grained members. The strata evaluated for this study are assigned to the Sandstone 1, which consists of three coarse-grained members (Bowl, Canyon, and Sage) separated by two fine-grained members (Happy Valley and Woolsey; Fig. 1d).

\section{Hydrogeology of the area}

The groundwater system underlying the study area is a part of the Simi Hills bounded by Simi Valley to the north, Box Canyon to the northeast, San Fernando Valley to the east, Bell and Las Virgenes Canyons to the south, and Runkle Canyon to the west (Fig. 2a). Previous investigators discussed the potential for subsurface groundwater outflow (i.e., deep and/or shallow) along the entire boundary of the groundwater system of the area (Fig. 2a), except for the western portion of the boundary (orange color in Fig. 2a) that is sub-parallel to the inferred direction of groundwater flow (MWH 2009). One of these studies (Cherry et al. 2009) integrated available literature data from direct measurements performed in the field area (MWH 2009; Williams and Knutson 2009) and set the bottom of fresh groundwater at approximately sea level. The upper boundary of the groundwater flow system is represented by the regional water table and localized perched water tables. At the scale of the mountain, the 


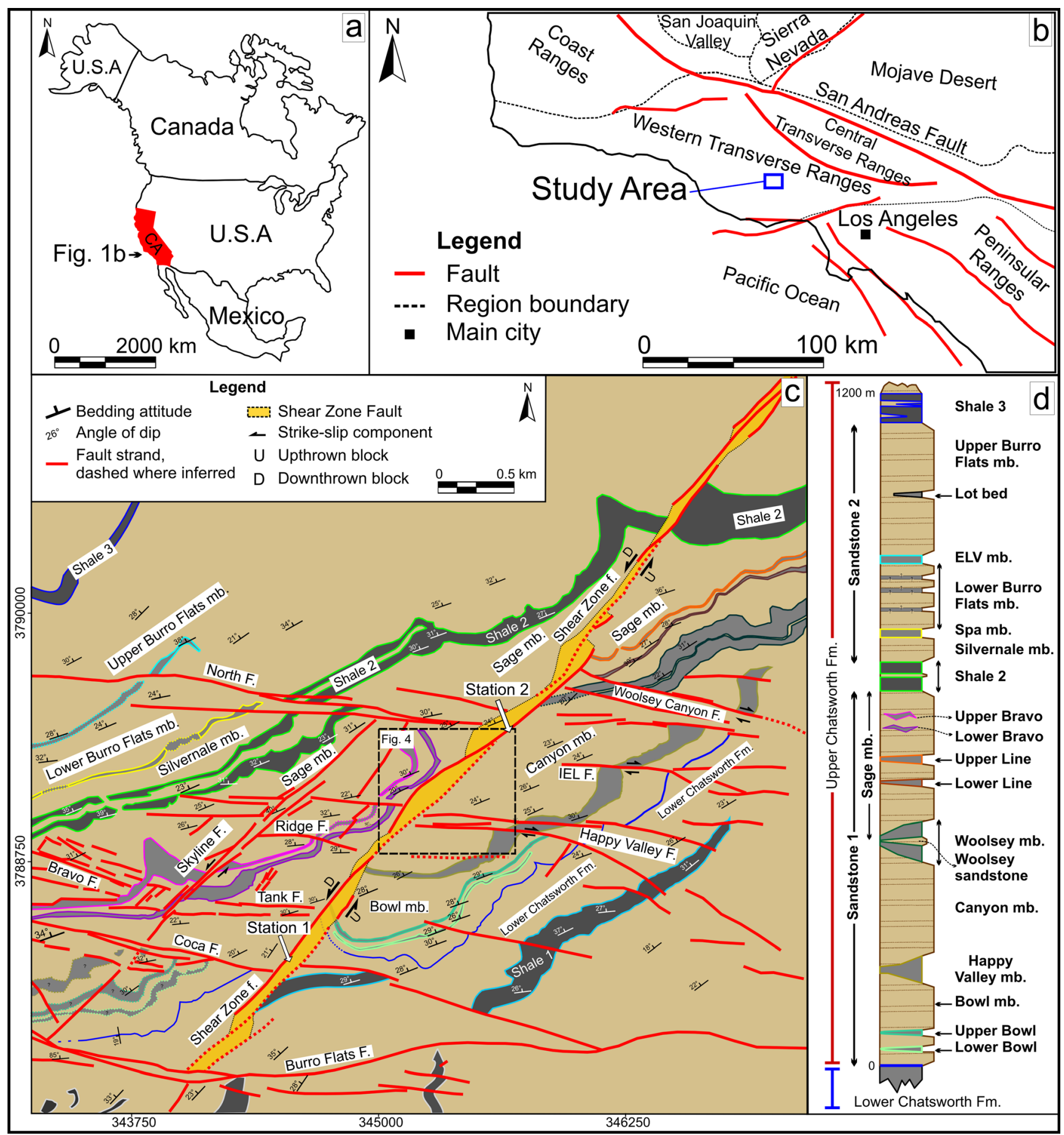

Fig. 1 a Map of USA and the adjacent countries; the state of California is shown in red. $\mathbf{b}$ Location of the study area in the Transverse Ranges Province of southern California, USA. c Simplified geological map of the study area showing ESE-WNW and NE-SW trending fault sets cutting across the Chatsworth Formation (modified from MWH 2009). The studied fault zone is highlighted by yellow infill; sandstone units are represented in khaki; shale and fine-grained units in different grey nuances. The locations where detailed analyses were carried out also are shown (black dashed rectangle and white arrows). d Stratigraphic column of the Chatsworth Formation in the vicinity of the study area (modified from MWH 2009). The numbers on the left side of the column represent its height, $m b .=$ member

water table is essentially a recharge mound that generally mimics the overall topography. However, some variability can be detected at the scale of the study area. Indeed, more than 350 monitoring wells and piezometers indicate that the depth of the water table ranges from 1 meter in the flat-lying areas to several hundred meters below ground Hydrogeology Journal (2015) 23: 405-419 surface beneath the topographic highs and some areas with residual drawdown from past pumping (Fig. 2b).

The members of the Upper Chatsworth Formation (Fig. 1) are differentiated by their texture such that each hydrogeologic unit (Fig. 2b) within the local groundwater flow system often can be correlated with the stratigraphic 
members (MWH 2009). The coarse-grained members (sandstones) store and transmit locally significant quantities of groundwater, and thus may be considered aquifer units (Fig. 2b). Conversely, the fine-grained members (i.e., mudstones, siltstones, and shales) tend to impede groundwater flow, and thus are considered aquitards (Fig. 2b). The other formations exposed near and beyond SSFL boundaries comprise hydrogeologic units that are more relevant toward the margins of the mountain groundwater system.

In the study area, both shallow and deep groundwater zones are recharged by the infiltration of precipitation, runoff, and runoff collected in ponds, with a relatively minor contribution from the incidental deep percolation of delivered municipal water. The spatial distribution of these groundwater zones is influenced by geologic factors (e.g., fine-grained units and faults), groundwater pumping, and recharge. Typically sharp inflections (up to 10 s of meters) of groundwater head occur across fine-grained units (Cherry et al. 2009). For example, more than $40 \mathrm{~m}$ of water level offset are detectable across Shale 2 (Fig. 2b). Furthermore, the presence of springs and flowing wells indicates the groundwater confinement effect of Shale 3 (MWH 2009). The shaley Woolsey member is one of the site's aquitards that affects the groundwater system. Indeed, the zones above and below this member exhibit water level differences solely due to the presence of this aquitard. Similar, but somewhat less pronounced effects are observed in association with thinner fine-grained units.

Two different sets of hydraulic head distribution data have been analyzed for this report: one was collected during the third quarter of 2008 (MWH 2009), and the other during the first quarter of 2014 (MWH 2014). Because these two datasets are very similar, Fig. 2(b) shows only the most recent one.

Groundwater occurrence and movement are also influenced by some of the tectonic structures (see arrows in Fig. 2b). As shown in Fig. 2b-c, groundwater levels differ by as much as $75 \mathrm{~m}$ across a major NE-SW striking fault zone called the "Shear Zone" (Sage 1971; MWH 2009), the subject of the present study. For consistency with former studies, this fault is referred to with its previously assigned name (Shear Zone fault or SZF), even though any well-developed fault is a shear zone in sensu stricto. The hydraulic heads on the southeast side of the fault are systematically higher than those on the northwest side. Despite this strong NW-SE (fault-perpendicular) groundwater hydraulic gradient, the migration of contaminant plumes is significantly restricted from east to west across SZF (Cherry et al. 2009).

The concentration of contaminants in groundwater monitored at various wells suggests that a comingled plume southeast of SZF is elongated in a direction parallel to SZF (MWH 2009). These observations are consistent with the hydraulic conductivity of the fault core of SZF, which was estimated to be $1 \times 10^{-9} \mathrm{~m} / \mathrm{s}$ based on groundwater-level offsets (Haley and Aldrich 2000), and $1 \times 10^{-10} \mathrm{~m} / \mathrm{s}$ based on pumping tests performed in a well located adjacent to this fault (MWH 2004). The aforementioned hydraulic conductivity values were then calibrated using a groundwater flow model (AquaResource/MWH 2007); the model calibrated values for different sections of SZF are potted in Fig. 3a. Figure $3 b$ is box-and-whisker plot comparing the bulk hydraulic conductivities of the two sandstone units surrounding the studied fault zone (i.e., Sage and Canyon members) and the conductivity of the SZF core (Haley and Aldrich 2000; MWH 2004; AquaResource/MWH 2007). This report will focus on the faulting mechanism responsible for the architecture of the Shear Zone fault and its consequent permeability structure.

A wide range of fault permeability structures have been observed at SSFL. For instance, evidence of enhanced hydraulic communication exists along the E-W striking North fault (northwestern portion of the map in Fig. 2b), which connects two zones of the aquifer that would be otherwise separated by Shale 2. Most of the other E-W striking faults, which generally occur within the thick sandstone units of the Chatsworth Formation, do not show significant evidence of reduced cross-fault conductivity (MWH 2009).

\section{Orientation and kinematics of the faults}

At SSFL, the Chatsworth Formation is crosscut by two dominant sets of faults: one trending NE-SW and generally showing an apparent left-lateral strike-slip kinematics and another roughly oriented ESE-WNW showing an apparent right-lateral strike-slip kinematics. Many of the faults shown in Fig. 1 have been described by a former remedial investigation geologist (MWH 2007, 2009, Appendix 4-J). The names of the individual structures are taken from the previous publications and are often related to toponyms of the study area. The length of the fault segments ranges from a few tens to a few thousands of meters. The major NE-SW oriented faults are, from east to west, the Shear Zone and Skyline faults. Whereas the faults in the ESE-WNW orientation from north to south are: Woolsey Canyon, North, IEL, Happy Valley, Ridge, Tank, Bravo, Coca, and Burro Flats. The ESE-WNW set appear to be predominant with respect to the NE-SW oriented set.

This study improved a previous fault map of SSFL and its surrounding (MWH 2007). For this task, the trace geometry and orientation of the faults were first investigated by aerial photograph analysis. Then, in order to describe the multiscale nature of these structures and assess their dimensional attributes, images at different scales and resolutions were

Fig. 2 a The large-scale hydraulic system and the detailed study area location (modified from MWH 2009). b Hydrogeological map of the Santa Susana Field Laboratory (modified from MWH 2014). The Shear Zone fault is highlighted by yellow infill. The hydraulic head elevation (blue lines) and well locations (solid circles) are shown. c Schematic cross-section $A-A^{\prime}$ in part b, showing the hydraulic head drop recorded in five wells located along an approximately E-W direction on either side of the Shear Zone fault (modified from MWH 2009). The inferred kinematics of the fault zone (west side down and toward viewer) also are shown 


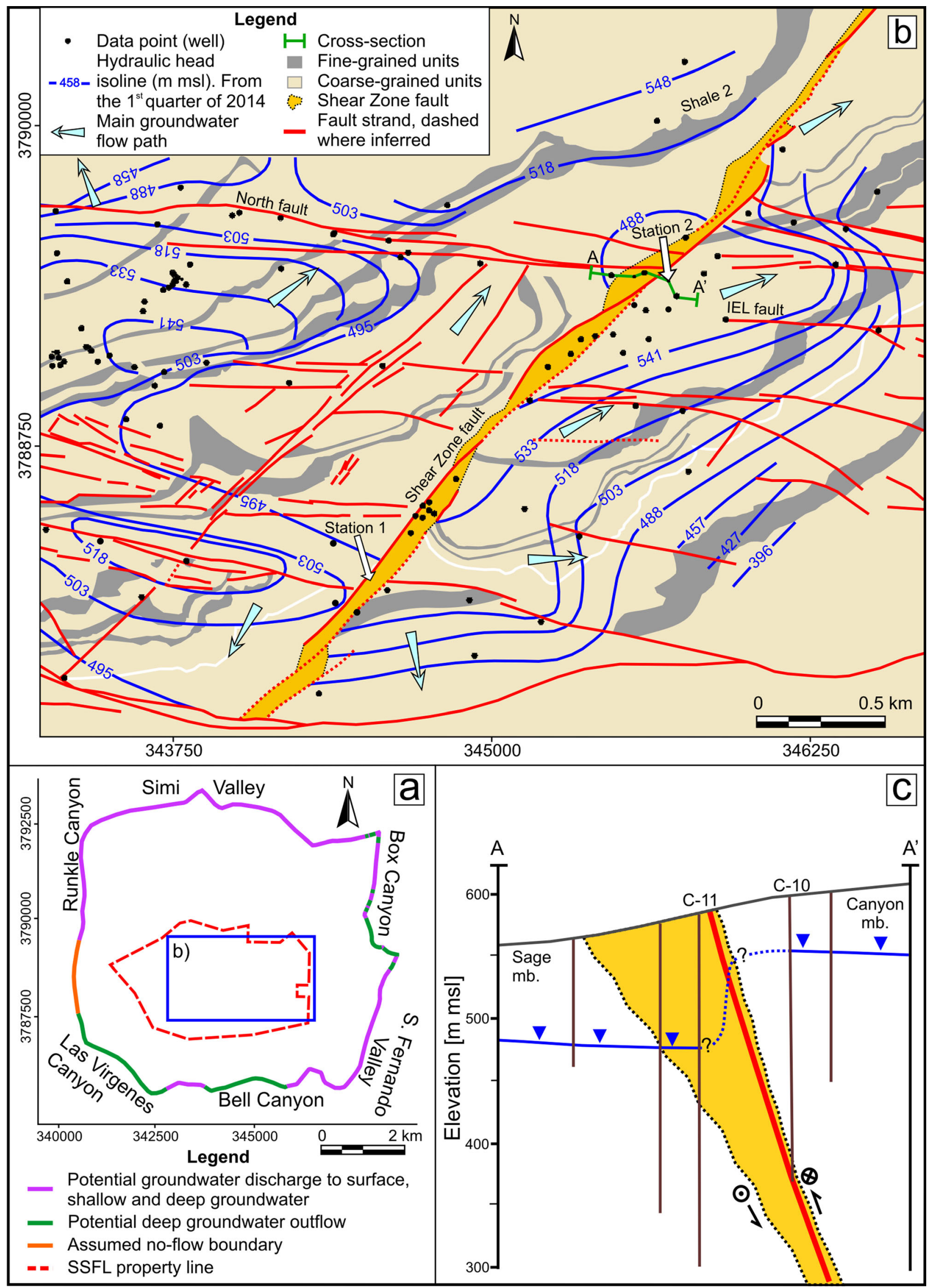




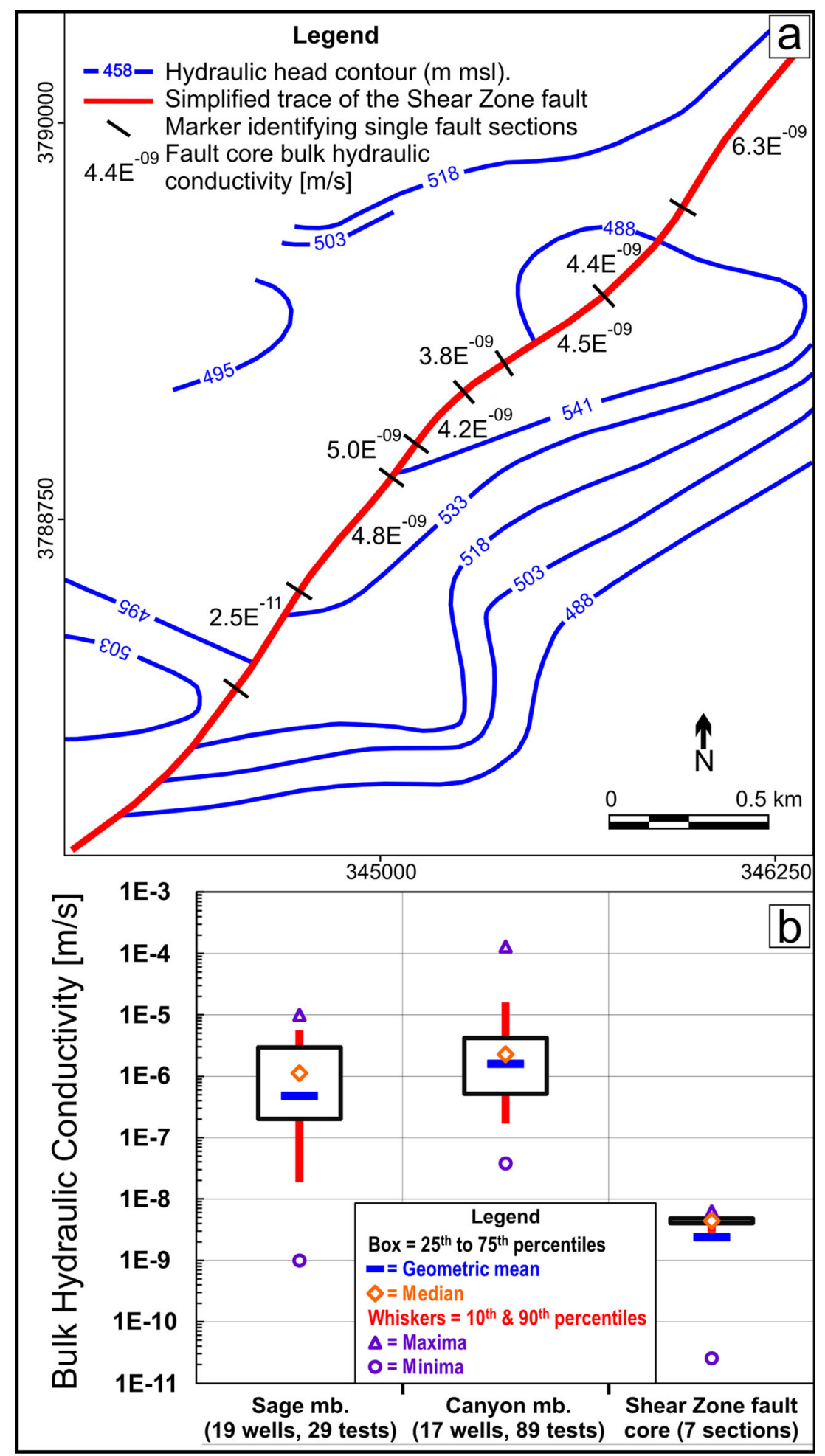

Fig. 3 Hydraulic conductivity data. a The hydraulic head contours from the first quarter of 2014 (blue lines; from MWH 2014), the schematic representation of SZF as drawn in the groundwater flow model (red line; redrawn from AquaResource/MWH 2007); the values of the hydraulic conductivity of the 6-m-thick fault core are listed adjacent to each section of the fault (from AquaResource/MWH 2007). b Box-and-whisker diagram of the hydraulic conductivity of the Shear Zone fault and the two surrounding sandstones

acquired from various databases (Google Earth images, aerial photographs taken from a helicopter, and ground photographs) and were analyzed. The criteria used to identify the fault zones shown in Fig. 1 were morphological Hydrogeology Journal (2015) 23: 405-419 expression and apparent stratigraphic offsets. The geometric complexity of the fault zones was captured by the identification of different fault segments, and the characterization of fault zone widths and extent of the damage zones. 


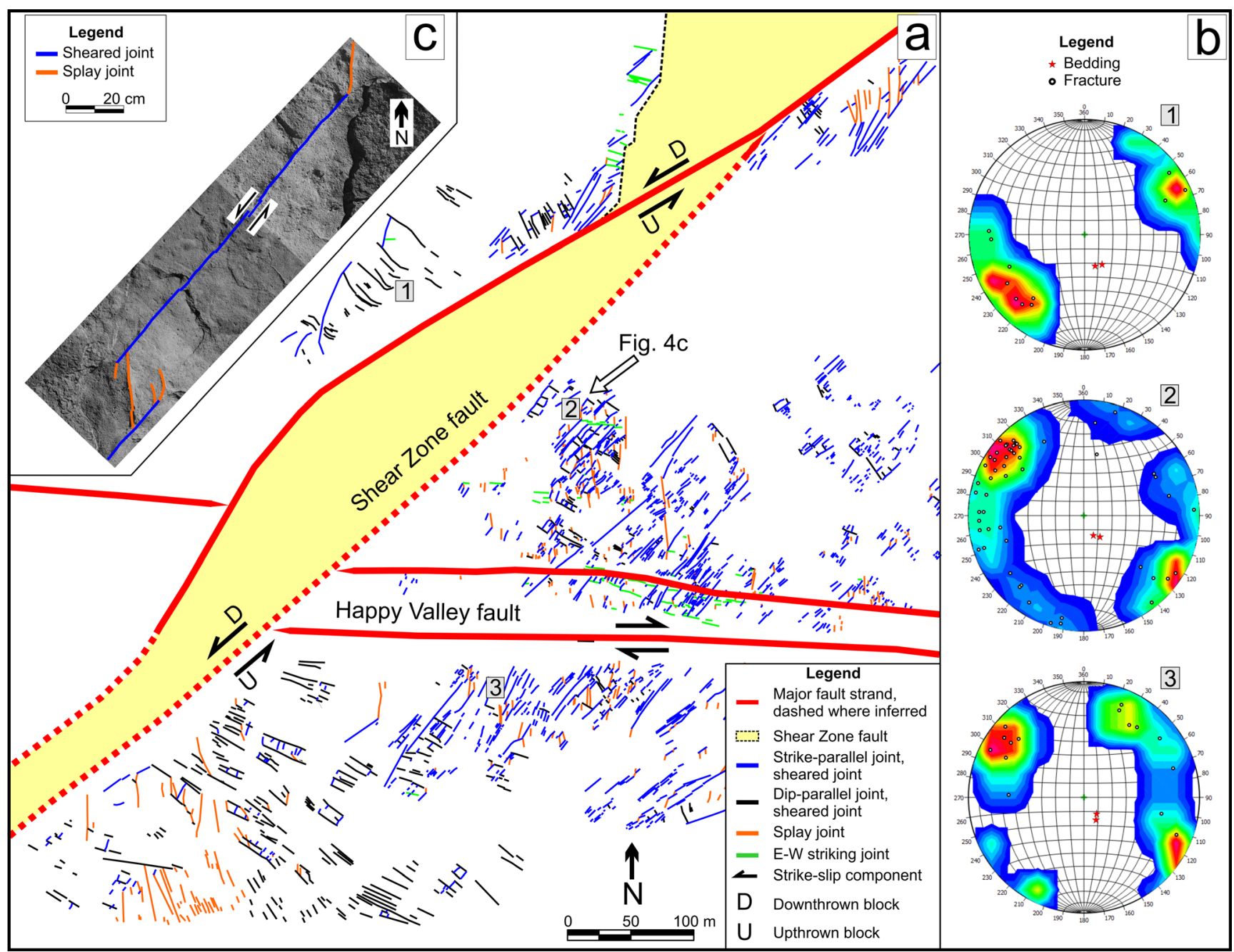

Fig. 4 a Detailed map of the area surrounding the left stepover between two of the segments of Shear Zone fault at the projected intersection with the Happy Valley fault (see location in Fig. 1). Each set of fractures is represented with a different color. b Orientation data collected from three different locations and plotted as poles on Smith's stereographic net lower hemispheres. c Interpreted ground picture of a sandstone crosscut by the splays (orange) of individual sheared joints and linked sheared joints (blue) from the NE-SW set

This analysis was followed by detailed field observations to verify the aerial photograph data and to constrain kinematic indicators across the fault zones.

\section{Shear Zone fault (SZF)}

The Shear Zone fault (SZF) is one of the major NE-SW striking fault zones, and is located in a critical remediation area within SSFL because of its vicinity to several of the former sources of contaminants. As seen in Figs. 2 and 3, this fault has a significant compartmentalization effect on the groundwater system. In this section, the geometry, kinematics, and architecture of the SZF are characterized.

The SZF is made up of several left-stepping, NE-SW oriented segments striking between $\mathrm{N} 40$ and $\mathrm{N} 55^{\circ} \mathrm{E}$. The fault has a total mapped length of at least $5.5 \mathrm{~km}$. However, this value is the integral of the contributions of multiple segments (Fig. 1). Within the study area more than nine segments were identified, the length of these segments ranges from a few hundreds of meters to about
$2 \mathrm{~km}$ (Fig. 1c). They overlap for about half of their lengths. The width of the fault zone is controlled in part by the spacing of the neighboring segments and varies significantly along strike (Figs. 1 and 4 ). The minimum width $(30 \mathrm{~m})$ was measured at the northern portion of the fault zone, where it comprises two closely spaced subparallel segments at the surface. Conversely, one of the largest widths $(150 \mathrm{~m})$ is observed along the central portion of the fault where two en echelon neighboring segments are far apart and form a left stepover (Fig. 4a).

The apparent left-lateral horizontal separation along the SZF can be measured at two locations at the surface. The first one is along the northern part of the fault where it offsets the Shale 2 by about $75 \mathrm{~m}$, and the second one is along the southern portion of the fault where the SZF offsets, by about $225 \mathrm{~m}$, a stratum assumed to represent the top boundary of the Lower Chatsworth formation. The SZF is characterized by a minor dip-slip component, too, based on the fact that the rocks exposed on the southeast side of the fault zone are always from a lower stratigraphic level with respect to those on the northwestern side (Fig. 1d). 


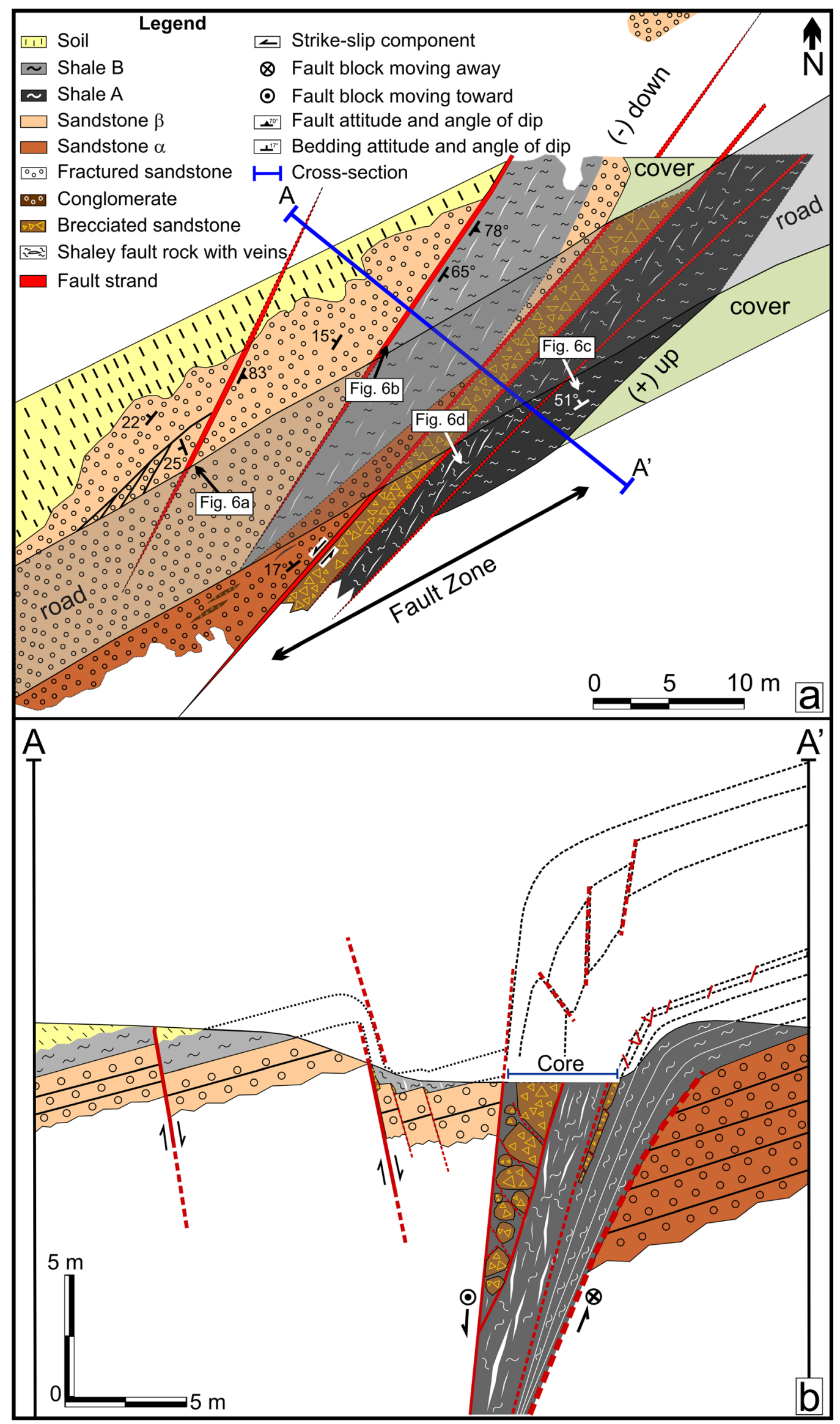


4Fig. 5 Map and cross-section of the Shear Zone fault at Station 1. a Detailed map showing several strands within the fault zone and the shale dipping toward the fault zone. b Interpretative cross-section of the fault zone showing the shale unit gradually dipping towards the fault zone with an increasing dip-angle and eventually merging into the fault core at depth. This is known as "shale smearing"

\section{Fault architecture}

The key aspects of the architecture of the SZF were delineated at two stations (Nos. 1 and 2) about $2 \mathrm{~km}$ apart from each other (see Fig. 1 for the locations). Station 1 encompasses an outcrop along the southern portion of the fault (Figs. 5a and 6), while Station 2 includes a borehole interpreted as intersecting the central portion of the fault and one of the shale units offset at depth (Fig. 7c-d). The former has the advantage of showing a transversal section of the fault zone in a large surface, whereas the latter reveals an image of a portion of the fault zone at the subsurface thereby avoiding effects of weathering and the related cover.
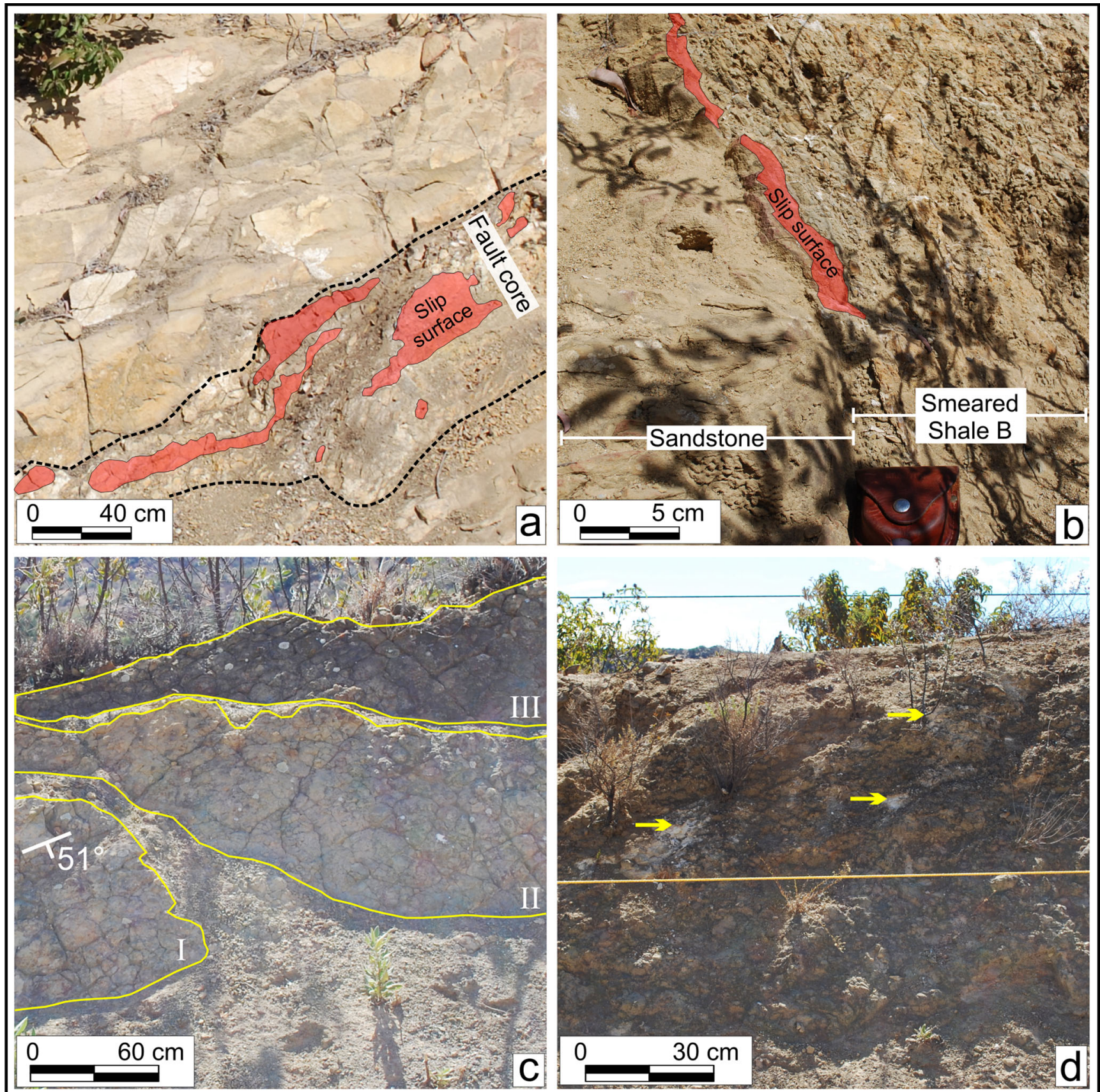

Fig. 6 Photographs of different portions of the Shear Zone fault at Station 1. a Fault strand in sandstones; closely-spaced slip surfaces are highlighted in red (due NW); b Smearing of shale unit "B" along a secondary fault strand (due NE); c Shale unit "A" highly bent and dipping toward the fault zone (due SE). I, II, and III represent distinct beds dipping towards the viewer and their boundaries are highlighted in yellow; d Shale-rich fault core with carbonate veins pointed out by yellow arrows (due SE) 


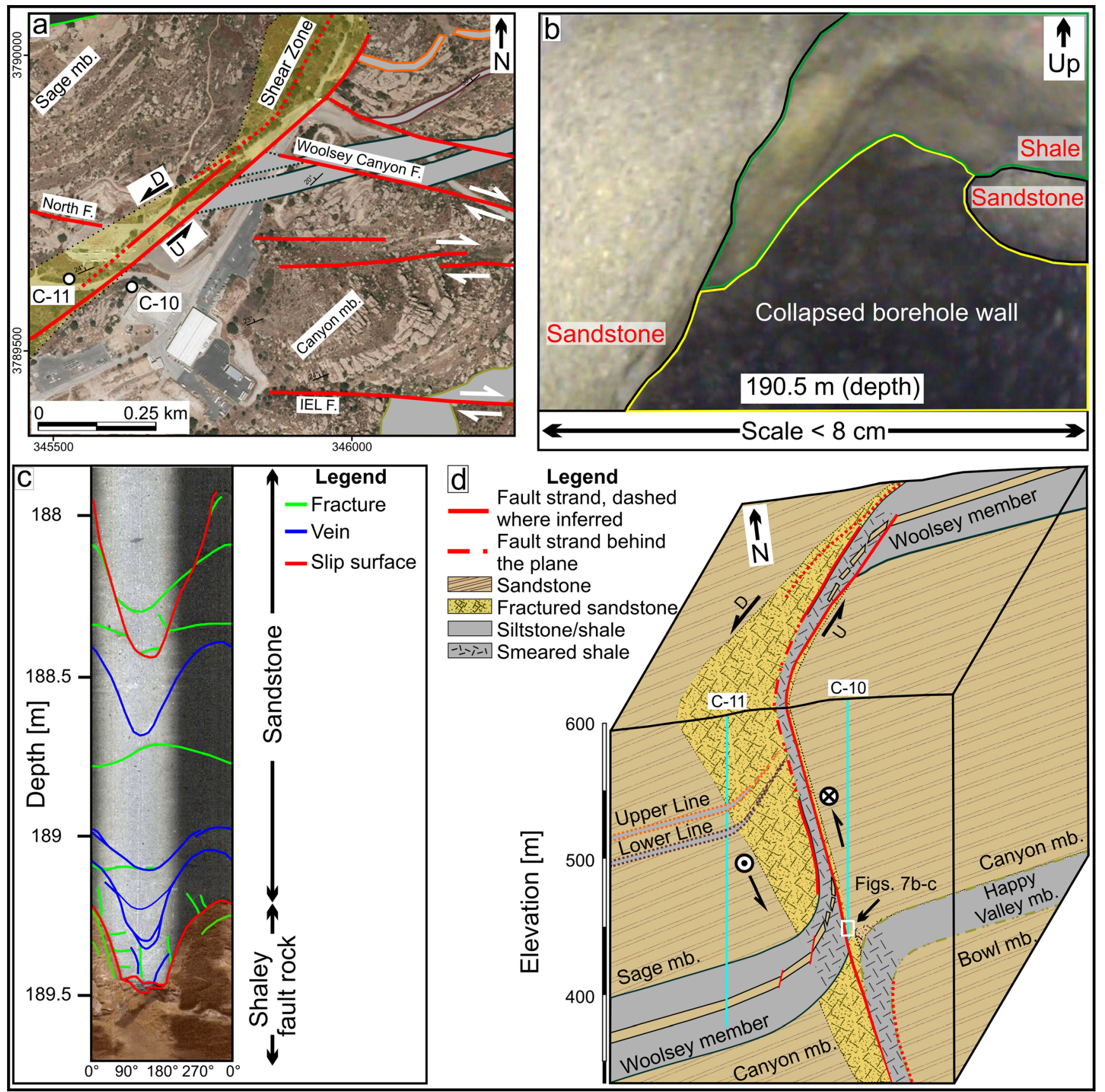

Fig. 7 Station 2 with borehole $C$ - 10 intersecting the Shear Zone fault and borehole $C$ - 11 intersecting the Woolsey member at depth. a Map of the northeast edge of SSFL with well locations marked. b Bent shale (green line boundary) juxtaposed to sandstone (black line boundary). c Interpreted image from the OPTV showing fractures, sheared fractures, veins, and slip surfaces. d Schematic 3D block diagram showing the SZF at this location. The well traces (turquoise) and their intersection with the Woolsey member and the Shear Zone fault are shown. Approximate locations of figure parts $b-c$ also are marked

\section{Station 1}

At this location the fault zone trends about $\mathrm{N} 50^{\circ} \mathrm{E}$ and is about 15 m-wide (Fig. 5a). It juxtaposes a highly deformed sandstone on the northwest side of the road and a shale-rich fault rock on the southeast side. Five major strands can be recognized within the fault zone (Fig. 5a). In the sandstone, the offsets were resolved along $\mathrm{N} 42^{\circ} \mathrm{E}$ striking and steeply SE-dipping slip surfaces localized within a $40-\mathrm{cm}$ wide sub-vertical strand of the fault (Fig. 6a). Further to the east, another SE-dipping Hydrogeology Journal (2015) 23: 405-419 fault strand marks the contact between a sandstone sliver and the deformed shale unit "B" (Fig. 5a). The sandstone beds, although intensely fractured, dip NW by about $20^{\circ}$, consistent with the general attitude of the bedding in the study area. The deformed shale is sub-parallel to the average fault zone and dips SE by about $65^{\circ}$ (Fig. 6b). Several meters to the northeast, the same shale unit crops out in its normal stratigraphic position dipping $20^{\circ} \mathrm{NW}$.

The central core of the fault zone is about $8 \mathrm{~m}$ wide and it is predominantly made up of shales characterized by a strong 

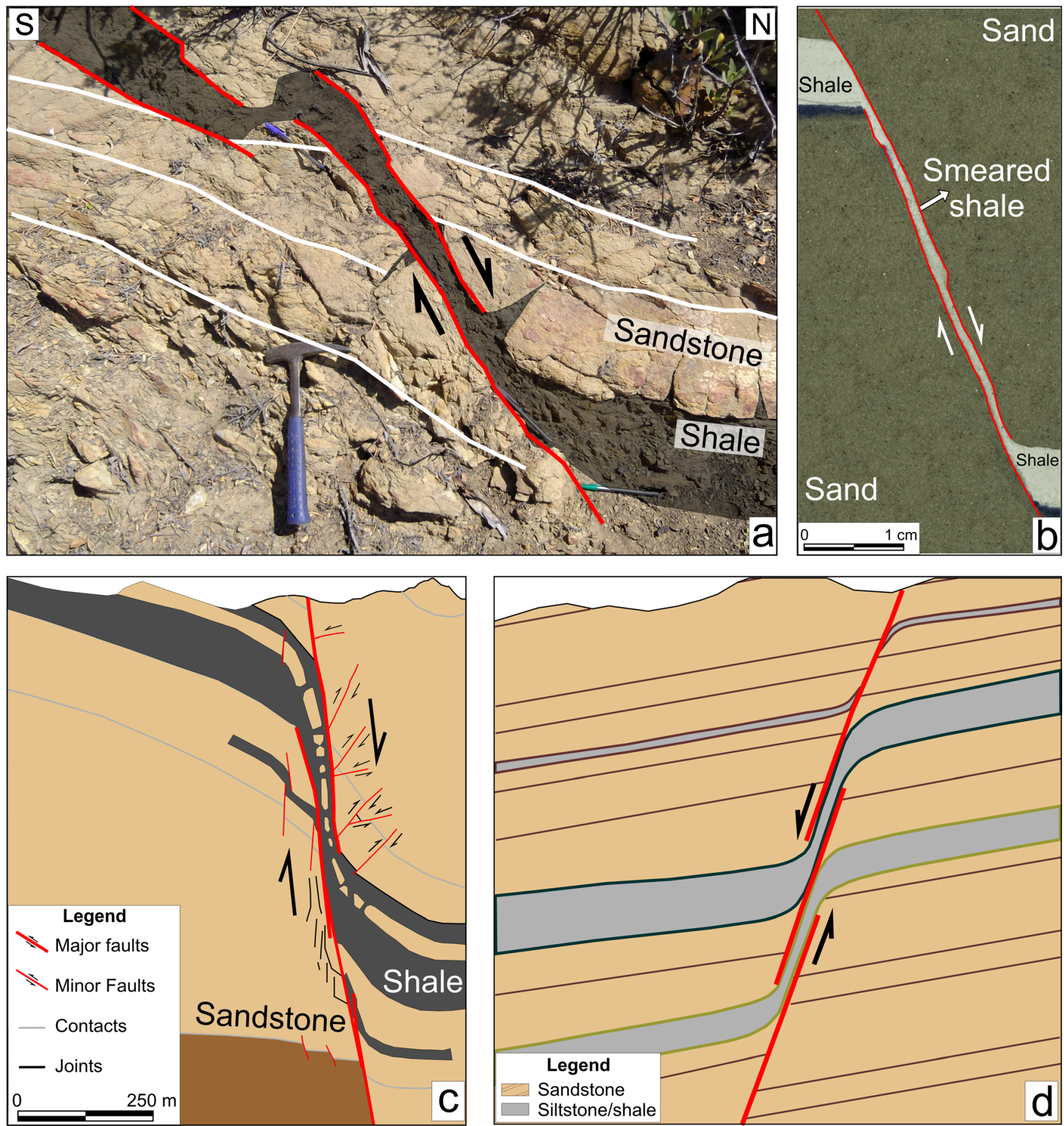

Fig. 8 Examples of faults with shale smearing. a An outcrop scale dip-slip fault zone exposed along CTL IV Road within the study area; fault segments are represented in red, sandstone bedding in white, shale bed has been shaded; b sand box analog model showing a single shale layer smeared along an extensional step-over of two segments of a normal fault (simplified and re-drawn from Noorsalehi-Garakania et al. 2013); c field-based conceptual model of a normal fault cross-cutting a sequence of alternating sandstones and shales (slightly modified from Aydin and Eyal 2002); d conceptual model of shale smearing in an alternating sequence of sandstones and shales. A thin shale unit becomes discontinuous across the fault zone, whereas thick shale units are incorporated between fault stopovers and merge together

diffuse deformation with a foliated texture sub-parallel to the fault zone (Figs. 5a and 6d). The fault core is overprinted by a $\mathrm{N} 30^{\circ} \mathrm{E}$-striking array of carbonate veins; its clay content decreases westward closer to the juxtaposition of the footwall sandstone against the shale fault rock (Figs. 5a and 6d).

Hydrogeology Journal (2015) 23: 405-419
At the southeastern edge of the exposure, the shale unit "A" dips towards the fault zone with a northwesterly strike and $50^{\circ}$ dip angle (Fig. $6 \mathrm{c}$ ). This part of the outcrop provided the key piece of data to infer that the shale unit gradually changed its dip angle and merged into the fault zone in a 


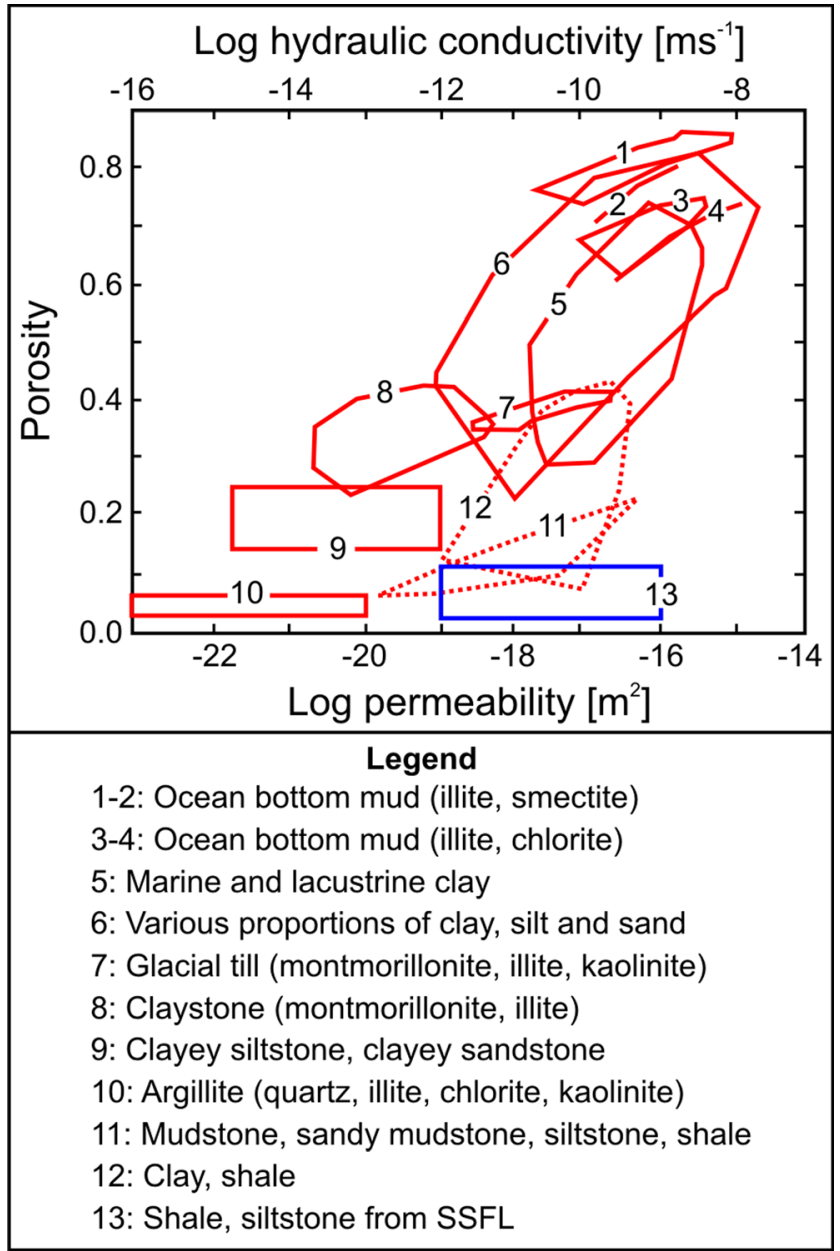

Fig. 9 Plot of laboratory-derived permeability versus porosity for a variety of natural argillaceous rocks (Neuzil 1994). Fields (outlined in red) denote the range of result values determined for each clay-rich rock type listed in the legend. Permeability is shown along the lower horizontal scale: the corresponding hydraulic conductivity of water at room temperature is shown along the upper horizontal scale. Numbers for each field correspond to lithologies stated in the legend (Neuzil 1994 and references therein). Fields 1-4: bottom deposits from North Pacific; 5 Pleistocene to recent from Quebec (Canada), Mississippi Delta (USA) and Sweden; 6 from Gulf of Mexico; 7 Southerland Group from Saskatchewan (Canada); 8 Pierre Shale from South Dakota (USA); 9 from western Canada; 10 Elena Formation from Nevada (USA); 11 from Japan and Alberta (Canada); 12 Upper Triassic, mid-Miocene, lower Pleistocene from Italy; 13 Shale and siltstone members from the Upper Cretaceous Chatsworth Formation, nominally unfractured rock cores (Hurley et al. 2007)

manner consistent with shale smearing (Weber et al. 1978). The interpretative cross-section presented in Fig. 5b was constructed based on the surface data and shows schematically how the major shale unit was incorporated or smeared along the fault zone.

\section{Station 2}

This station includes the borehole C-10 (see Fig. 7a for location), which reaches a depth of approximately $194 \mathrm{~m}$. Previous investigators (MWH 2009) interpreted that near its bottom (at about $189 \mathrm{~m}$ ) this borehole intersects the fault zone (Fig. 7d). Geophysical data (i.e., gamma-ray, electric resistivity, and optical televiewer) were available for this well. Images from the optical televiewer (OPTV) were interpreted and integrated with ex-situ characterization of the last $6 \mathrm{~m}$ of the recovered rock core. Figure $7 \mathrm{c}$ shows the interpreted OPTV image where fractures (including sheared fractures or faults), veins, and slip surfaces are identified and highlighted with different colors. At the bottom of the image (189.2 m depth) a slip surface juxtaposes fractured sandstones against highly deformed shale fault rock. This slip surface, which dips $75^{\circ}$ toward SE, is here interpreted as the southeastern boundary of the Shear Zone fault (Fig. 7d). About $4 \mathrm{~m}$ of shale fault rock were captured in the core. The shale fault rock was highly folded and brecciated with a locally complex cataclastic texture. A semi-quantitative x-ray diffraction analysis was performed on two representative samples of the shale fault rock to identify their mineralogical composition. Both samples displayed a similar composition dominated by plagioclase (50-80\%) and clay minerals (saponite and vermiculite; $20-50 \%$ ). A very small amount (3-5\%) of quartz also was found in one of the samples. Similar to the observations at Station 1, the shales show a plastic behavior in contrast to the brittle behavior of the sandstones. One image taken at the depth where the fault zone boundary was inferred shows a highly bent shale strata juxtaposed against a sandstone sliver (Fig. 7b). The architecture of the SZF in the subsurface, consisting of plastic shale bent against fractured sandstones and shale-rich fault rock, resembles that documented at the surface at Station 1. Therefore, it is suggested that the mechanism of incorporating shale into the fault zone is the same in both portions of the fault.

This station also has a borehole, C-11, (see Fig. 7a for location) intersecting what is inferred to be the fine-grained ( $45 \%$ of the bulk composition) Woolsey member at around $185 \mathrm{~m}$ depth, thereby revealing the throw of the Woolsey member. On the southeast side of the fault zone the Woolsey member crops out $230 \mathrm{~m}$ northeast of borehole C-11, suggesting an apparent vertical separation along the SZF of about 170 m (Fig. 7d).

Because definitive kinematic indicators for the exact slip direction were not found, the true slip direction and slip magnitude of the fault could not be determined. However, based on the geometric relationship between the SZF and the Woolsey member, the two end-member values for possible offsets were calculated: a pure strike-slip $\left(0^{\circ}\right.$ rake) motion of $230 \mathrm{~m}$ would give $42 \mathrm{~m}$ of an apparent vertical separation, whereas a pure dip-slip $\left(90^{\circ}\right.$ rake) motion of $170 \mathrm{~m}$ would imply a maximum $70 \mathrm{~m}$ of left-lateral apparent offset. Based on this simple exercise, it is inferred that the SZF must have an oblique-slip with lateral and vertical components bracketed by 230 and $170 \mathrm{~m}$, respectively.

\section{Discussion}

The Shear Zone fault is one of the members of the NESW trending set of an apparent conjugate fault system cutting across inter-bedded sandstone and shale sequences 
of the Chatsworth Formation an upper Cretaceous turbidite deposit exposed the Simi Hills section of the Western Transverse Range Province of southern California. At the surface, the fault zone is mapped as greater than $5.5 \mathrm{~km}$ in length and is composed of several segments with en echelon geometry. The segment lengths are generally on the order of 1-2 km, they overlap for about half of their lengths in a sense that, when viewed along strike, the next segment steps to the left. The widths of the stepovers, which are expressed by a negative relief, define approximately the fault zone width varying from 30 to $150 \mathrm{~m}$ at the surface. These observations are consistent with the inferred dominant left-lateral slip component across the fault zone and its growth by the linkage of neighboring segments similar to those described by other authors at various locations (Cartwright et al. 1995; de Joussineau and Aydin 2007; Aydin and Berryman 2010).

The Shear Zone fault is interpreted as also segmented down dip. This is by and large due to the shale and finegrained members of the Chatsworth Formation, which initially demark the en-échelon segments localized within the sandstone members. Eventually, shale and fine-grained members get incorporated into the extensional stepovers between vertically discontinuous fault segments by a mechanism known as shale smearing (Fig. 8, Lehner and Pilaar 1997; Aydin and Eyal 2002). If a few hard data points available from the study area can be generalized, the fault rock is made up of fairly continuous smeared shale with enough thickness and coherence along the fault zone to form a partial hydraulic barrier. The hypothesis of continuous shale smear along the fault zone is also supported by the presence of multiple shale-rich units within the Chatsworth Formation. In fact, each one of these units represents an additional source of shales incorporated within the fault zone. Figure $8 \mathrm{~d}$ shows that thin shale beds become discontinuous across a fault zone if the throw thickness ratio is greater than 7 (according to Lindsay et al. 1993), whereas thicker shale units may merge together during the smearing process. The smearing of multiple shale units increases the possibility of a continuous fault sealing along the fault dip direction (Schmatz et al. 2010).

Although the Shear Zone fault has a total offset on the order of several tens of meters, it is not clear if the entire offset occurred with a continuous and consistent sense. Given that the broader region encompassing the study area has undergone a sequence of compression, rotation, extension, and subsequent compression (Nicholson et al. 1994), it is likely that the total offset estimated today was achieved through several stages of overlapping faulting processes with different kinematics. However, the sense of the dominant left-lateral horizontal component is consistent with the remote stress field currently affecting the Western Transverse Ranges province, which is characterized by a horizontal maximum remote compressive stress oriented roughly N-S (Langenheim et al. 2011). These postulated inversions had consequences that are difficult to decipher without additional detailed field work.

Sedimentary units dominated by clays and shales are known to have lower hydraulic conductivity with respect to most other lithologies: hydraulic conductivities between $10^{-16}$ and $10^{-10} \mathrm{~m} / \mathrm{s}$ have been reported from laboratory and regional studies of such rocks (Fig. 9). The hydraulic conductivity and porosity measurements performed on nominally unfractured shale and siltstone cores from SSFL are reported in Fig. 9 (blue polygon) for comparison. Shale smear and re-orientation of the platy clay minerals along the fault zones may produce fault rocks which are less permeable than the undeformed parent shales (Yielding et al. 1997; Eichhubl et al. 2005; Aydin 2014). The sealing potential of the faults with smeared shale fault rocks varies from case to case. A displacement capillary pressure $30 \%$ higher in a subsurface fault zone with respect to underformed shales was measured at the Black Diamond Mine in California (Eichhubl et al. 2005). A permeability reduction of up to three orders of magnitude between a shale-rich fault gouge and the surrounding sandstone aquifer was calculated for some faults crosscutting the Lower Rhine Embayment (Bense and Van Balen 2004).

Similar to many other examples reported in the literature (e.g., Bense and Van Balen 2004; Bense and Person 2006; Færseth 2006 and Bense et al. 2013), it is possible to detect a significant difference between the hydraulic heads measured at tens of wells on either sides of the Shear Zone fault (MWH 2004; Cherry et al. 2009; MWH 2009). The estimated hydraulic conductivity of the core of the Shear Zone fault is up to several orders of magnitude lower than the bulk hydraulic conductivity of the surrounding sandstones (Fig. 3b), and generally lower than the shale-rich units (Haley and Aldrich 2000; Sterling 2000; MWH 2004). As shown in Fig. $2 b$ the hydraulic head on the southeastern side of the fault is always higher than that of the northwestern side. These data support that, despite the large number of segments present at the surface, the Shear Zone fault has a continuous sealing capacity with respect to cross-fault flow. Similar outcomes were obtained by modeling anisotropic fault zones crosscutting alternating sandstone and shale sequences (Bense and Person 2006). The hydraulic head differences are not equal along the fault strike (Figs. 2 and 3 ). Maximum drops in hydraulic head across the SZF are measured along its northern and central portions where the fault crosscuts two thick fine-grained units (i.e., Shale 2 and Woolsey member).

The sealing potential of the fault rocks of the SZF is relevant with respect to the potential for NW-SE faultperpendicular groundwater flow. However, the faultrelated fracture pattern mapped in the sandstone units exposed adjacent to the SZF (Fig. 4a) appears to be highly interconnected and could, for instance, cause an anisotropy of the fault-parallel hydraulic conductivity (similar to that reported by Bense and Person 2006).

This study focused on the permeability structure of one of the largest fault zones crosscutting SSFL area. However, there are other faults with $\mathrm{E}-\mathrm{W}$ trends, some of which occur only within thick sandstone units. These faults have different architecture and permeability structures with respect to the SZF, and this poses intriguing questions that will be addressed in a future study.

DOI 10.1007/s10040-014-1206-1 


\section{Conclusions}

The Shear Zone fault is characterized by an oblique-slip kinematics with a large left-lateral strike-slip component and some normal-slip component. The exact magnitudes of these components are not known but some end members on the orders of a few hundred and several tens of meters, respectively, are inferred. It is also proposed that the normal and strike-slip mechanisms may have operated sequentially in accordance with the changing tectonic stresses operating across the broader region.

The fault probably nucleated by means of shearing and linkage of pre-existing discontinuities such as joints within the brittle sandstone units, whereas the shale units deformed in a ductile manner. The overall mechanism of incorporating shale into the fault zone is inferred to be shale smearing. However, uncertainties exist regarding the impact of overprinting normal and strike-slip faulting mechanisms on the continuity and integrity of the smeared shale fault rock.

The fault zone has a width ranging from 30 to $150 \mathrm{~m}$ and a fault core thickness ranging between 4 and $8 \mathrm{~m}$ that is rich in clay minerals (from 20 to $50 \%$ ). The drop of hydraulic head detected across the fault segments is interpreted to be primarily due to low-conductivity shale fault rock. This is also consistent with the hydraulic conductivity of the fault core, which was calculated to be ranging between $\mathrm{E}^{-11}$ and $\mathrm{E}^{-09} \mathrm{~m} / \mathrm{s}$ by previous investigators (Fig. 3).

Despite the high degree of segmentation of this fault zone, which could imply local diminution of the sealing capacity of the whole structure, none of the observation wells appears to show any clear hydrogeological evidence of enhanced cross-fault groundwater flow between the segment stepovers. Overall, this study helps fill the gap between the hydrogeological and structural geologic data, and should be helpful to model and constrain the migration of contaminants in the subsurface.

Acknowledgements This study was carried out in collaboration with Dr. J. Cherry and Dr. B. Parker from the University of Guelph, G360 Centre for Applied Groundwater Research; the site consultant R. Andrachek from MWH Americas Inc. Logistical support and participation of the site owner, the Boeing Company and their project manager, M. Bower, is appreciated. We wish to thank E.T. Vander Velde and J. Likerman for the help provided during the field campaigns, and Dr. W. Yiming for performing the x-ray diffraction analysis. An early version of this manuscript has been reviewed by Dr. G. Hazelton from MWH. This version of the manuscript has benefited from the comments of the associate editor E. Shalev, two anonymous reviewers and S. Duncan.

Open Access This article is distributed under the terms of the Creative Commons Attribution License which permits any use, distribution, and reproduction in any medium, provided the original author(s) and the source are credited.

\section{References}

Agosta F, Ruano P, Rustichelli A et al (2012) Inner structure and deformation mechanisms of normal faults in conglomerates and carbonate grainstones (Granada Basin, Betic Cordillera, Spain): inferences on fault permeability. J Struct Geol 45:4-20
Antonellini M, Aydin A (1994) Effect of faulting on fluid flow in porous sandstones: petrophysical properties. Am Assoc Pet Geol Bull 78:355-377

Antonellini M, Cilona A, Tondi E et al (2014) Fluid flow numerical experiments of faulted porous carbonates, northwest Sicily (Italy). Mar Pet Geol 55:86-201

Aydin A (2000) Fractures, faults and hydrocarbon migration and flow. Mar Pet Geol 17:797-814

Aydin A (2014) Failure modes of shales and their implications for natural and manmade fracture assemblages. In: Ferrill DA (ed) AAPG Bulletin Special Issue on Faulting and Fracturing in Shale and Self-Sourced Reservoirs. doi:10.1306/07311413112

Aydin A, Berryman JG (2010) Analysis of the growth of strike-slip faults using effective medium theory. J Struct Geol 32(11):1629-1642

Aydin A, Eyal Y (2002) Anatomy of a normal fault with shale smear: implications for fault seal. AAPG Bull 86:1367-1381

AquaResource, Inc/MWH (2007) Three-dimensional groundwater flow model report, Santa Susana Field Laboratory, Ventura County, CA. AquaResource, Waterloo, ON

Balsamo F, Storti F, Salvini F et al (2010) Structural and petrophysical evolution of extensional fault zones in poorly lithified low-porosity sandstones of the Barreiras Formation, NE Brazil. J Struct Geol 32:1806-1826

Bense VF, Person MA (2006) Fault zones as conduit-barrier systems to fluid flow in siliciclastic sedimentary aquifers. Water Resour Res 42, W05421. doi:10.1029/2005WR004480

Bense VF, Person M, Chaudhary K et al (2008) Thermal anomalies as indicator of preferential flow along faults in an unconsolidated sedimentary aquifer system. Geophys Res Lett 35, L24406

Bense VF, Gleeson T, Loveless SE et al (2013) Fault zone hydrogeology. Earth Sci Rev 127:171-192

Bense VF, Van Balen RT (2004) The effect of fault relay and clay smearing on groundwater flow patterns in the Lower Rhine Embayment. Basin Res 16:397-411

Bouma AH (1962) Sedimentology of some flysch deposits: a graphic approach to facies interpretation. Elsevier, Amsterdam, $168 \mathrm{pp}$

Bredehoeft JD, BackW, Hanshaw BB (1982) Regional groundwater flow concepts in the United States: historical perspective. In: Narasimhan TN (ed) Recent trends in hydrogeology. Geological Soc Am Spec Pap 189:297-316

Caine JS, Evans JP, Forster CB (1996) Fault zone architecture and permeability structure. Geology 24:1025-1028

Cartwright JA, Trudgill BD, Mansfeld CS (1995) Fault growth by segment linkage: an explanation for scatter in maximum displacement and trace length data from the Canyonlands Grabens of SE Utah. J Struct Geol 17:1319-1326

Celico F, Petrella E, Celico P (2006) Hydrogeological behaviour of some fault zones in a carbonate aquifer of Southern Italy: an experimentally based model. Terra Nova 18(5):308-313

CH2MHill (1993) Records search and trichloroethylene sssessment for Santa Susana Field Laboratory, Ventura County, CA, vols 1 -2 . Technical report, $\mathrm{CH} 2 \mathrm{MHill}$, Englewood, $\mathrm{CO}$

Cherry JA, David B, McWhorter et al (SSFL Groundwater Advisory Panel) (2009) Site conceptual model for the migration and fate of contaminants in groundwater at the Santa Susana Field Laboratory, Simi, California (draft), vols 1-4. In Association with the University of Guelph, Toronto, ON; MWH, Walnut Creek, CA; Haley and Aldrich, Burlington, MA and AquaResource, Portland, OR

Cohen AJB (1999) Three-dimensional numerical modeling of the influence of faults on groundwater flow at Yucca Mountain, Nevada. PhD Thesis, Ernest Orlando Lawrence Berkeley National Laboratory, Berkeley, CA

Colburn IP, Saul LER, Almgren AA (1981) The Chatsworth Formation: a new formation name for the Upper Cretaceous strata of the Simi Hills, California. SEPM, Tulsa, OK

de Joussineau G, Aydin A (2007) The evolution of the damage zone with fault growth in sandstone and its multiscale characteristics. J Geophys Res 112, B12401 
Eichhubl P, D'Onfro P, Aydin A et al (2005) Structure, petrophysics, and diagenesis of shale entrained along a normal fault at Black Diamond Mines, California: implications for fault seal. AAPG Bull 89(9):1113-1137

Engelder T (1974) Cataclasis and the generation of fault gouge. Geol Soc Am Bull 85:1515-1522

Færseth RB (2006) Shale smear along large faults: continuity of smear and the fault seal capacity. J Geol Soc Lond 163:741-751

Faulkner DR, Jackson CAL, Lunn RJ et al (2010) A review of recent developments concerning the structure, mechanics and fluid flow properties of fault zones. J Struct Geol 32:1557-1575

Flodin E, Gerdes M, Aydin A et al. (2005) Petrophysical properties and sealing capacity of fault rock, Aztec Sandstone, Nevada. In: Sorkhabi R, Tsuji Y (eds) Faults, fluid flow, and petroleum traps. AAPG Memoir 85, AAPG, Tulsa, OK, pp 197-217

Haley and Aldrich Inc. (2000) Santa Susana field laboratory hydrogeology summary report, Appendix B. In: Conceptual site model, movement of TCE in the Chatsworth Formation, Santa Susana Field Laboratory, Ventura County, CA. Technical memorandum prepared by Montgomery Watson, Walnut Creek, CA

Hurley JC, Parker BL, Cherry JA (2007) Source zone characterization at the Santa Susana Field Laboratory: rock core VOC results for coreholes C1-C7. Final report, Dept. of Earth Sciences, University of Waterloo, Waterloo, ON

Langenheim VE, Wright TL, Okaya DA et al (2011) Structure of the San Fernando Valley region, California: implications for seismic hazard and tectonic history. Geosphere 2:528-572

Lehner FK, Pilaar WF (1997) The emplacement of clay smears in synsedimentary normal faults: inferences from field observations near Frechen, Germany. In: Møller-Pedersen P, Koestler AG (eds) Hydrocarbon seals: importance for exploration and production. Elsevier, Amsterdam, pp 39-50

Lindsay NG, Murphy FC, Walsh JJ et al (1993) Outcrop studies of shale smears on fault surfaces. In: Flint SS Bryant ID (eds) The geological modelling of hydrocarbon reservoirs and outcrop analogues. Int. Assoc. of Sedimentologists Spec Publ. 15, IAS, Gent, Belgium, pp 113-123

Link MH, Squires RL, Colburn IP (1981) Simi Hills Cretaceous turbidites, southern California. Field trip guidebook, Pacific Section of the Society of Economic Paleontologists and Mineralogists. pacificsectionsepm.org. Accessed October 2014

Link MH, Squires RL, Colburn IP (1984) Slope and deep-sea fan facies and paleogeography of Upper Cretaceous Chatsworth Formation, Simi Hills, California. AAPG Bull 68(7):850-873

Micarelli L, Moretti I, Jaubert M et al (2006) Fracture analysis in the southwestern Corinth Rift (Greece) and implications on fault hydraulic behavior. Tectonophysics 426:31-59

Mitchell TM, Faulkner DR (2009) The nature and origin of off-fault damage surrounding strike-slip fault zones with a wide range of displacements: a field study from the Atacama fault zone, northern Chile. J Struct Geol 31:802-816

Montgomery Watson (2000) Conceptual site model: movement of TCE in the Chatsworth Formation, Santa Susana Field Laboratory. Montgomery Watson, Walnut Creek, CA

MWH (2004) Phase I of northeast area groundwater characterization, Santa Susana Field Laboratory, vols 1-3. Report of results, MWH, Walnut Creek, CA
MWH (2007) Geologic characterization of the Central Santa Susana Field Laboratory. Prepared for The Boeing Company by MWH, Walnut Creek, CA, 90 pp

MWH (2009) Draft site-wide groundwater remedial investigation report Santa Susana Field Laboratory, Ventura County, California, vols 1-4. Prepared for The Boeing Company, NASA, and US DOE by MWH, Walnut Creek, CA

MWH (2014) Groundwater Monitoring Progress Report, First Quarter 2014, Santa Susana Field Laboratory, Ventura County, CA. Prepared for The Boeing Company, NASA, and US DOE by MWH, Walnut Creek, CA

Neuzil CE (1994) How permeable are clays and shales? Water Resour Res 302:145-150

Nicholson C, Sorlien CC, Atwater T et al (1994) Microplate capture, rotation of the western Transverse Ranges, and initiation of the San Andreas transform as a low angle fault system. Geology 22:491-495

Noorsalehi-Garakania S, Kleine Vennekate GJ, Vrolijk $P$ et al (2013) Clay-smear continuity and normal fault zone geometry: first results from excavated sandbox models. J Struct Geol 57:58-80

Petrella E, Aquino D, Fiorillo F et al (2014). The effect of lowpermeability fault zones on groundwater flow in a compartmentalized system: experimental evidence from a carbonate aquifer (southern Italy). Hydrological Processes. doi: 10.1002/ hyp. 10294

Rotevatn A, Fossen H (2011) Simulating the effect of subseismic fault tails and process zones in a siliciclastic reservoir analogue: implications for aquifer support and trap definition. Mar Pet Geol 28:1648-1662

Sage OG Jr (1971) Geology of the eastern portion of the "Chico" Formation, Simi Hills, California. MSc Thesis, University of California, Santa Barbara, CA, 109 pp

Schmatz J, Vrolijk PJ, Urai JL (2010) Clay smear in normal fault zones: the effect of multilayers and clay cementation in water-saturated model experiments. J Struct Geol $32: 1834-1849$

Sterling S (2000) Hydraulic aperture determinations from borehole information in the Chatsworth Formation, appendix C. In: Conceptual site model: movement of TCE in the Chatsworth Formation, Santa Susana Field Laboratory, Ventura County, CA (Montgomery Watson, 2000a). MWH, Walnut Creek, CA

Taylor WL, Pollard DD, Aydin A (1999) Fluid flow in discrete joint sets: field observations and numerical simulations. J Geophys Res 104:28983-29006

Weber KJ, Mandl G, Pilaar WF et al (1978) The role of faults in hydrocarbon migration and trapping in Nigerian growth fault structures. Society of Petroleum Engineers AIME 10th Annual Offshore Conference Proceedings, vol 4 , SPE, Richardson, TX, pp 2643-2653

Williams JH, Knutson KD (2009) Integrated analysis of flow, temperature, and specific-conductance logs and depthdependent water-quality samples from three deep wells in a fractured-sandstone aquifer, Ventura, California. US Geol Surv Open-File Rep 2009-1023

Yielding G, Freeman B, Needham DT (1997) Quantitative fault seal prediction. AAPG Bull 81:897-917 